\title{
ANALISIS PENGAMBILAN KEPUTUSAN NASABAH PEMBIAYAAN MURABAHAH PADA BMT DAARUT TAUHIID BANDUNG
}

\author{
Asep Suryanto ${ }^{1 *}$, Adah Sa'adah ${ }^{2}$ \\ ${ }^{1}$ Program studi Ekonomi Syariah,Universitas Siliwangi, asepsuryanto@unsil.ac.id \\ ${ }^{2}$ Program studi Ekonomi Syariah,Universitas Siliwangi, adahsaadah361@ gmail.com
}

\begin{abstract}
The objective of this research was to find out what factors underlie Daarut Tauhiid BMT customers in applying of murabaha financing. The research method used is descriptive research method with a qualitative approach. The data sources in this study involve primary data sources and secondary data sources. Primary data sources, namely the unit head, account officer, and members of Daarut Tauhiid BMT as murabaha financing customers at the BMT. Secondary data sources involve modules, documents at Daarut Tauhiid BMT relating to the topic of research. The data analysis techniques are through the stages of data reduction, data display and data verification. The results of the research show that the factors that could underlie customer decisions in applying_The results showed that the factors underlying the customer's decision in applying of murabaha financing at Daarut Tauhiid Baitul mal wa Tamwil (BMT) were images of the Daarut Tauhiid environment, reference groups, customer needs in certain situations, supporting personal work, customer perceptions of syariah compliance.
\end{abstract}

Keywords: decision making, murabaha financing, and customers.

\begin{abstract}
ABSTRAK
Tujuan dalam penelitian ini adalah untuk mengetahui faktor-faktor apa saja yang melatarbelakangi anggota sebagai nasabah BMT Daarut Tauhiid dalam mengajukan pembiayaan murabahah. Metode penelitian yang digunakan adalah metode penelitian deskriptif dengan pendekatan kualitatif. Sumber data dalam penelitian ini meliputi sumber data primer, yaitu kepala unit, account officer, dan anggota BMT Daarut Tauhiid sebagai nasabah pembiayaan murabahah di BMT tersebut. Sumber data sekunder yang meliputi modul, dokumen-dokumen di BMT Daarut Tauhiid yang berkaitan dengan topik penelitian. Adapun teknik analisis data melalui tahapan reduksi data, penyajian data dan verifikasi data. Hasil penelitian menunjukan bahwa faktor-faktor yang dapat melatarbelakangi keputusan nasabah dalam mengajukan pembiayaan murabahah di baitul mal wa Tamwil (BMT) Daarut Tauhiid adalah citra tentang lingkungan Daarut Tauhiid, kelompok referensi, kebutuhan nasabah pada situasi tertentu, penunjang pekerjaan pribadi, persepsi nasabah tentang kesyariahan BMT.
\end{abstract}

Kata kunci: pengambilan keputusan, pembiayaan murabahah, dan nasabah.

\footnotetext{
1*Penulis korespondensi, asepsuryanto@ unsil.ac.id
} 


\section{PENDAHULUAN}

BMT (Baitul Maal Wat Tamwil) merupakan lembaga keuangan mikro, yang secara bahasa terdiri dari dua kata yaitu Baitul Maal dan Baitul tamwil. BMT dalam fungsi Baitul Maal merupakan lembaga yang berfungsi dalam mengumpulkan dan menyalurkan dana non profit seperti zakat, infak dan sedekah. Sedangkan BMT dalam fungsi baitul tamwil merupakan lembaga keuangan syariah yang berfungsi sebagai lembaga keuangan bisnis dalam kegiatan funding maupun landing yang bertujuan untuk komersial.tentunya dengan menggunakan skema-skema funding dan landing syariah.

Peran BMT sebagai lembaga keuangan mikro memberikan kontribusi pada perekonomian untuk kalangan masyarakat menengah ke bawah yang tidak dijangkau oleh kegiatan perbankan. BMT sebagai lembaga keuangan mikro syariah memiliki fungsi yang meliputi penghimpunan dana dan penyaluran dana masyarakat. Funghsi penghimpunan dana di BMT menggunakan skema seperti produk wadiah, mudharabah, simpanan berjangka, dll. Sedangkan fungsi penyaluran dananya lebih diarahkan kepada pembiayaan usaha mikro dengan menggunakan skema pembiayaan syariah seperti pembiayaan mudharabah, pembiayaan murabahah, pembiayaan musyarakah, dan lain-lain.

Salah satu produk yang dibutuhkan oleh masyarakat adalah pembiayaan murabahah. Skema pembiayaan ini yang banyak dipilih oleh masyarakat karena memberikan kemudahan dan membantu masyarakat untuk meningkatkan kegiatan usahanya atau untuk keperluan konsumsi dalam pemenuhan kebutuhan hidup sehari-hari. Berdasarkan data Otoritas Jasa Keuangan (OJK), pembiayaan yang disalurkan kepada masyarakat didominasi oleh skema murabahah. Persentase pembiayaan didominasi oleh pembiayaan murabahah yang mencapai 54,03\% dari total pembiayaan yang disalurkan Rp. 325,69 triliun pada tahun 2017.

BMT Daarut Tauhiid merupakan salah satu lembaga keuangan mikro syariah yang terdapat di kota Bandung. Meskipun BMT ini adalah unit dari Kopontren Daarut Tauhiid, pada kenyataannya BMT Daarut Tauhid ini mampu berkembang dan merebut pangsa pasar yang didominasi oleh lembaga keuangan perbankan. Berdasarkan data yang diperoleh, jumlah anggota BMT Daarut Tauhid per 31 Desember 2016 mencapai 2.001 orang, dan meningkat per 31 Desember 2017 dengan jumlah anggota mencapai 3.000 orang.

Berdasarkan data dari BMT Daarut Tauhiid ternyata pembiayaan yang menjadi prioritas adalah pembiayaan Murabahah. Pembiayaan ini adalah paling banyak digemari oleh anggota BMT. Jumlah pembiayaan yang dikeluarkan oleh BMT Daarut Tauhiid pada tahun 2017 sebesar Rp. 21.917.740.809,-. Dari sudut pandang pengelola BMT, pembiayaan murabahah lebih diutamakan karena resikonya lebih sedikit dibandingkan dengan pembiayaan dengan skema yang lain, karena pihak BMT telah menetapkan kesepakatan dengan anggota BMT baik dari segi pembayaran maupun jumlah margin yang tetapkan oleh BMT.

Sementara dari perspektif anggota pemilihan skema pembiayaan lebih mengutamakan kemudahan dibandingkan dengan alasannya lainnya. Padahal tidak semua kebutuhan pembiayaan cocok hanya dengan menggunakan skema murabahah, baik dari aspek syariah maupun aspek keadilan dalam penentuan margin. Misalnya, 1) kebutuhan pembiayaan anggota 
untuk keperluan sekolah tidak akan cocok jika menggunakan skema pembiayaan murabahah tetapi harus menggunakan skema ujrah; 2) kebutuhan pembiayaan anggota untuk keperluan permodalan usaha, tidak akan cocok jika menggunakan skema pembiayaan murabahah akan tetapi harus menggunakan skema musyarakah.

Pada sisi yang lain perkembangan jumlah anggota yang mengambil pembiayaan ke BMT Daarut Tauhiid dengan skema murabahah dari tahun 2011 s/d 2018 secara umum mengalami kenaikan tetapi pada tahun 2015 berkurang dan tahun 2018 mengalami penurunan yang tajam melebihi penurunan yang terjadi pada tahun 2015. Ini menunjukkan bahwa keputusan anggota untuk melakukan pembiayaan murabahah mengalami penurunan. Data penurunan jumlah anggota yang mengajukan pembiayaan murabahah di BMT Daarut Tauhiid tersebut dapat digambarkan sebagai berikut :

\section{Gambar 1}

Jumlah Anggota Pembiayaan Murabahah

Baitul Mal wa Tamwil Daarut Tauhiid Bandung

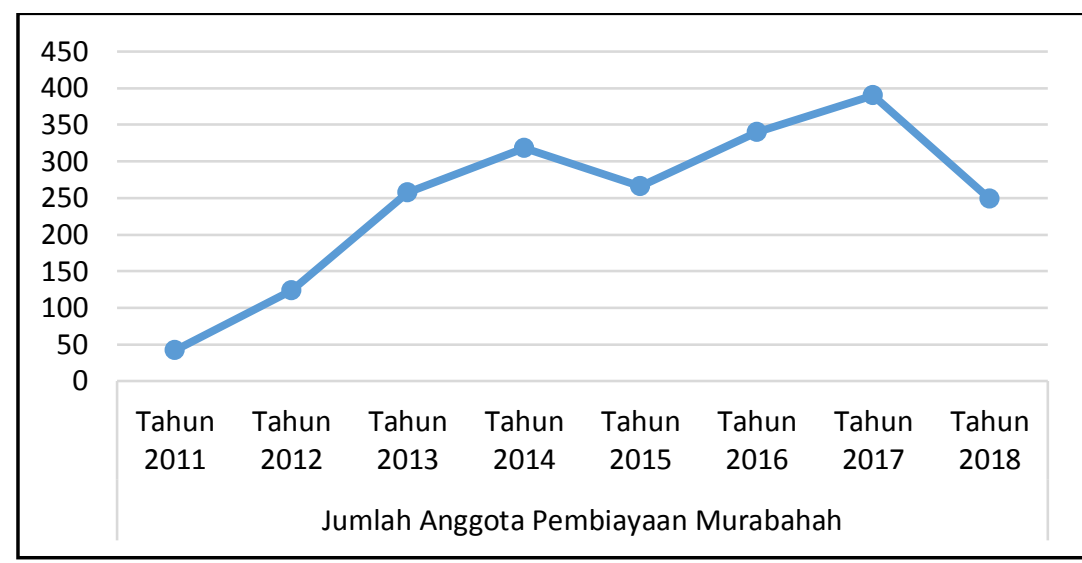

Sumber : BMT Daarut Tauhiid, diolah.

Apabila permasalahan tersebut dilihat dari perspektif anggota BMT, maka muncul pertanyaan, apa yang menjadi latar belakang anggota BMT Daarut Tauhiid dalam mengambil keputusan skema pembiayaan Murabahah?

\section{LITERATUR REVIEW}

\section{Pengambilan Keputusan Konsumen}

Keputusan adalah proses penelusuran masalah yang berawal dari latar belakang masalah, identifikasi masalah hingga kepada terbentuknya kesimpulan atau rekomendasi. Keputusan pembelian merupakan tahap dalam proses pengambilan keputusan sampai konsumen benarbenar membeli produk. Keputusan pembelian konsumen (purchase decision) adalah pembelian merk yang paling disukai. Namun, ada dua faktor yang bisa muncul diantara niat untuk membeli 
dan mengambil keputusan pembelian yang mungkin mengubah niat tersebut. Faktor pertama adalah sikap orang lain, dan faktor kedua adalah situasi yang tidak diharapkan (Irham Fahmi, 2014). Sementara Peter dan Olson (Etta Mamang Sangadji \& Sopiah, 2013), mendefinisikan pengambilan keputusan sebagai sebuah proses pemecahan masalah yang diarahkan pada sasaran. Intinya adalah proses pengintegrasian yang mengkombinasikan pengetahuan untuk mengevaluasi dua perilaku alternatif atau lebih dan memilih salah satu diantaranya.

Menurut kotler dan amstrong (Donni Juni Priana, 2017), proses yang digunakan konsumen untuk mengambil keputusan pembelian terdiri atas lima tahap, yaitu : 1) Pengenalan Masalah. Keputusan pembelian diawali dengan adanya kebutuhan dan keinginan konsumen, dimana dalam hal ini konsumen menyadari adanya perbedaan antara keadaan yang sebenarnya dengan keadaan yang diinginkannya. Kebutuhan tersebut dapat digerakkan oleh rangsangan dari dalam diri konsumen itu sendiri maupun berasal dari luar diri konsumen. 2) Pencarian Informasi. Setelah konsumen menyadari adanya kebutuhan terhadap produk tertentu, selanjutnya konsumen tersebut mencari infromasi, baik yang berasal dari pengetahuannya maupun berasal dari luar. Sumber informasi konsumen digolongkan ke dalam empat golongan, yaitu : a) Sumber pribadi yang terdiri dari keluarga, teman, tetangga, dan kenalan; b) Sumber komersial yang terdiri dari iklan, wiraniaga, penyalur dan kemasan; c) Sumber publik yang terdiri dari media masa, organisasi penentu peringkat konsumen; d) Sumber pengalaman yang terdiri dari pengalaman dalam penanganan, pengkajian dan pemakai produk. 3) Evaluasi Alternatif. Setelah informasi diperoleh, konsumen mengevaluasi berbagai alternatif pilihan dalam memenuhi kebutuhan tersebut. Evaluasi alternatif seperti lamanya waktu pemakaian produk, kualitas produk, lokasi perusahaan maupun spesifikasi dari produk dan jasa yang akan dibeli oleh konsumen. 4) Keputusan Pembelian. Apabila tidak ada faktor lain yang mengganggu setelah konsumen menentukan pilihan yang telah ditetapkan, maka pembelian yang aktual adalah hasil akhir dari pencarian dan evaluasi yang telah dilakukan. 5) Evaluasi Pasca Pembelian. Apabila produk yang dibeli tidak memberikan kepuasan yang diharapkan, maka konsumen akan merubah sikapnya terhadap merek tersebut menjadi sikap negatif bahkan mungkin menolak produk tersebut dikemudian hari. Sabaliknya, bila konsumen mendapat kepuasaan dari produk yang dibelinya, maka keinginan untuk membeli terhadap produk tersebut akan menjadi lebih kuat.

Gambar 2

Proses Pengambilan Keputusan

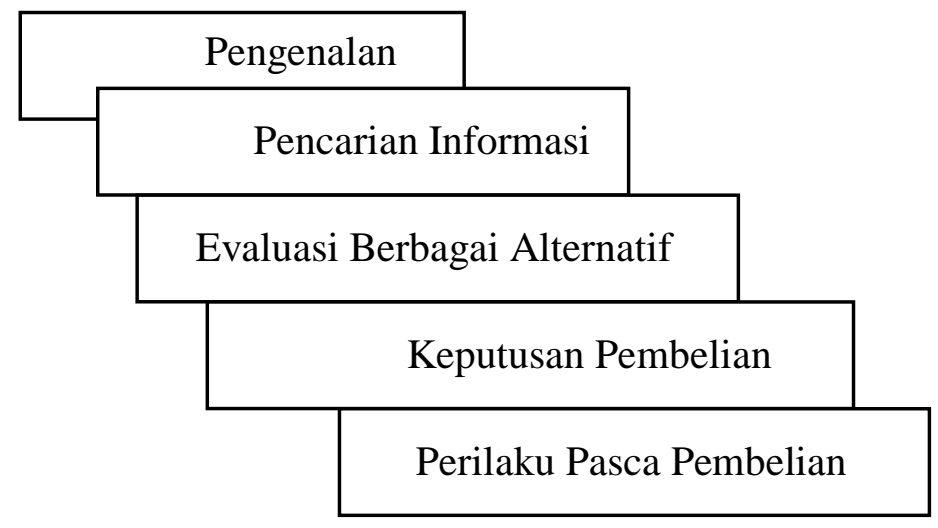




\section{Faktor-Faktor Utama Penentu Keputusan Pembelian Konsumen}

\section{Faktor-faktor kebudayaan}

a. Kebudayaan.

Budaya (Nugroho J. Setiadi, 2013) merupakan variabel yang mempengaruhi perilaku konsumen yang tercermin pada cara hidup, kebiasaan, dan tradisi dalam perminataan akan bermacam-macam barang dan jasa yang ditawarkan. Keanekaragaman dalam kebudayaan suatu daerah akan membentukn perilaku konsumen yang beragam pula. Menurut Engel (Etta Mamang Sangaji \& Sopiah, 2013) budaya dipengaruhi oleh makrobudaya dan mikrobudaya. Makrobudaya mengacu pada perangkat nilai dan simbol yang berlaku pada keseluruhan masyarakat, sedangkan mikrobudaya lebih mengacu pada perangkat nilai dan simbol dari kelompok yang lebih terbatas, seperti kelompok agama, etnis, atau sub bagian dari keseluruhan.

Kebudayaan merupakan faktor penentu yang paling besar dari keinginan dan perilaku seseorang. Budaya adalah seperangkat nilai, persepsi, preferensi,keinginan dan perilaku melalui suatu proses sosialisasi yang yang melibatkan keluarga dan lembaga-lembaga sosial lainnya (Nana Herdiana Abdurrahman, 2015). Budaya pembeli dapat menentukan keinginan dan perilaku seseorang yang tercermin pada insting dan perilaku manusia. Perilaku anak kecil berbeda dengan anak muda atau remaja dan orang dewasa, baik dalam nilai-nilai persepsi, preferensi dan perilaku melalui suatu proses sosialisasi (Sofjan Assauri, 2015).

b. Sub-Budaya

Setiap kebudayaan terdiri dari sub-budaya - sub-budaya yang lebih kecil yang memberikan identifikasi dan sosialisasi yang lebih spesifik untuk para anggotanya. Sub-budaya dapat digolongkan ke beberapa jenis yaitu: kelompok nasionalisme, kelompok keagamaan, kelompok geografis (Nugroho J. Setiadi, 2003).

Sub-budaya yang mempengaruhi perilaku konsumen dibedakan atas kelompok bangsa atau suku bangsa, kepercayaan atau agama, ras dan daerah geografis. Faktor ini mempengaruhi cara hidup, seperti preferensi makanan, pakaian, rekreasi, dan aspirasi karier (Sofjan Assauri, 2015).

c. Kelas sosial

Kelas-kelas sosial adalah kelompok-kelompok yang relatif homogen dan bertahan lama dalam suatu masyarakat yang tersusun secara hierarki dan keanggotaannya mempunyai nilai, minat dan perilaku yang serupa.

\section{Faktor-faktor Sosial}

Fakrot-faktor sosial menjadi salah satu faktor yang dapat mempengaruhi keputusan pembelian konsumen. (Nugroho J. Setiadi, 2003)

a. Kelompok Referensi 
Kelompok referensi seseorang terdiri dari seluruh kelompok yang mempunyai pengaruh langsung maupun tidak langsung terhadap sikap atau perilaku seseorang. Diantaranya adalah kelompok-kelompok primer, yang dengan adanya interaksi yang cukup berkesinambungan, seperti keluarga, teman, tetangga dan teman sejawat. Kelompok-kelompok sekunder, yang cenderung lebih resmi dan yang mana interaksi yang terjadi kurang berkesinambungan.

Orang orang yang dipengaruhi oleh kelompok-kelompok dimana mereka bukan anggotanya. Kelompok seseorang yang ingin masuk disebut dengan kelompok aspirasional. Sedangkan kelompok disokiatif adalah kelompok yang nilai atau perilakunya ditolak oleh seorang individu (Thamrin Abdullah \& Francis, 2016).

Kelompok referensi mempengaruhi anggota setidaknya dengan tiga cara. Mereka memperkenalkan perilaku dan dan gaya hidup baru kepada seseorang, mereka mempengaruhi konsep diri, dan mereka menciptakan tekanan kenyamanan yang dapat mempengaruhi pilihan produk dan merk (Philip Kotler, Kevin Lane Keller, 2008).

b. Keluarga

Seseorang dapat membedakan antara dua keluarga dalam kehidupan pembeli, yang pertama adalah keluarga orientasi yang merupakan orangtua seseorang. Dari sinilah seseorang mendapatkan ilmu tentang agama, politik, ekonomi, dan merasakan ambisi pribadi nilai atau harga diri dan cinta. Keluarga prokreasi adalah pasangan hidup anak-anak seseorang keluarga merupakan organisasi pembeli dan konsumen yang paling penting dalam suatu masyarakat dan telah diteliti secara intensif (Nugroho J. Setiadi, 2003).

c. Peran dan Status

Seseorang pada umumnya berpartisipasi dalam kelompok selama hidupnya, keluarga, klub, organisasi. Posisi seseorang dalam setiap kelompok dapat diidentifikasikan dalam peran dan status.

\section{Faktor Situasional}

Situasi dapat dipandang sebagai pengaruh yang timbul dari faktor yang khusus untuk waktu dan tempat yang spesifik yang lepas dari karakteristik konsumen dan karakteristik objek. Faktor situasinal meliputi lingkungan fisik dan waktu. Engel menjelaskan bahwa situasi konsumen sebenarnya dapat dipisahkan menjadi tiga, yaitu situasi komunikasi, situasi pembelian dan situasi pemakaian. Situasi komunikasi dapat didefinisikan sebagai latar konsumen ketika dihadapkan pada komunikasi pribadi atau nonpribadi. Komunikasi pribadi akan mencakup percakapan yang mungkin diadakan oleh konsumen dengan orang lain seperti wiraniaga atau sesama konsumen. Komunikasi nonpribadi akan melibatkan spektrum stimulus seperti iklan dan program, serta publikasi yang berorientasi konsumen. Situasi pembelian mengacu pada latar belakang dimana konsumen memperolah produk dan jasa. Jenis selebihnya dari situasi konsumen yang dibahas di sini adalah situasi pemakaian yang mengacu pada latar dimana konsumsi terjadi. (Etta Mamang Sangadji \& Sopiah, 2013) 


\section{Faktor Pribadi}

Faktor pribadi yang dapat mempengaruhi keputusan pembelian konsumen meliputi (Nugroho J. Setiadi, 2003) :

a. Umur dan Tahapan dalam Siklus Hidup

Konsumsi seseorang juga dibentuk oleh tahapan siklus hidup keluarga. Beberapa penelitian telah mengidentifikasi tahapan-tahapan dalam siklus hidup psikologis. Orang-orang yang sudah dewasa biasnya dapat mengalami perubahan atau transformasi pada saat mereka menjalani hidupnya.

b. Pekerjaan

Marketing biasanya berusaha untuk mengidentifikasi kelompok-kelompok pekerja yang memiliki minat di atas rata-rata terhadap produk dan jasa tertentu.

c. Keadaan Ekonomi

Keadaan ekonomi seseorang terdiri dari pendapatan yang dapat dibelanjakan (tingkatnya, stabilitasnya, dan polanya), tabungan dan hartanya (termasuk persentase yang mudah dijadikan uang), kemampuan untuk meminjam dan sikap terhadap mengeluarkan lawan menabung.

d. Gaya Hidup

Gaya hidup seseorang adalah pola hidup didunia yang diekspresikan oleh kegiatan, minat dan pendapat seseorang. Gaya hidup menggambarkan seseorang yang berinteraksi dengan lingkungan. Gaya hidup juga mencerminkan sesuatu dibalik kelas sosial seseorang.

e. Kepribadian dan Konsep Diri

Yang dimaksud dengan kepribadian adalah karakteristik psikologis yang berbeda dari setiap orang yang memandang responnya terhadap lingkungan yang reltif konsisten. Kepribadian merupakan suatu variabel yang sangat berguna dalam menganalisa perilaku konsumen. Jadi faktor pribadi yang mempengaruhi perilaku konsumen atau pembeli barangbarang konsumsi terdiri dari tingkat siklus kehidupan (life cycle stage) dan umur pembeli, pekerjaan, keadaan ekonomi, cara hidup (life style), kepribadian, dan konsep diri sendiri (self concept), yaitu bagaimana seseorang melihat dirinya sendiri (Sofjan Assauri, 2015).

\section{Faktor-faktor Psikologis}

Faktor psikologis yang dapat mempengaruhi keputusan pembelian konsumen meliputi (Nugroho J. Setiadi, 2003) :

a. Motivasi

Kebutuhan ini timbul dari suatu psikologis tertentu, seperti rasa lapar, rasa haus, dan rasa tidak nyaman. Sedangkan kebutuhan-kebutuhan lain bersifat psikogenik yaitu kebutuhan yang timbul dari keadaan fisiologis tertentu, seperti kebutuhan untuk diakui, kebutuhan harga diri dan kebutuhan diterima.

b. Persepsi

Persepsi diartikan sebagai suatu proses dimana seseorang memilih, mengorganisasikan, mengartikan masukan informasi untuk menciptakan suatu gambaran yang berarti di dunia. Orang dapat memiliki persepsi yang berbeda dari objek yang sama karena adanya tiga proses 
persepsi yaitu perhatian yang selektif, gangguan yang selektif, dan mengingat kembali yang selektif. Faktor-faktor persepsi ini adalah perhatian, gangguan, dan mengingat yang selektif artinya bahwa para orang dalam bidang pemasaran harus bekerja keras agar pesan yang disampaikan diterima (Sofjan Assauri, 2015).

c. Proses Belajar.

Proses menjelaskan perubahan dalam perilaku seseorang yang timbul dari pengalaman.

d. Kepercayaan dan Sikap.

Kepercayaan adalah suatu gagasan deskriptif yang dimiliki seseorang terhadap sesuatu.

\section{Pembiayaan Murabahah}

Pembiayaan Murabahah merupakan salah satu produk pembiayaan yang dijalankan oleh bank syariah, yaitu bentuk pembiayaan dengan menggunakan skema jual beli suatu barang (keperluan yang diajukan oleh nasanah kepada bank) antara bank dengan nasabah dengan harga pembelian ditambah margin sesuai kesepakatan antara bank syaraih dengan nasabah (Ikit, 2018). Pembiayaan ini dilakukan dengan ketentuan-ketentuan sebagai berikut :

Pertama, ketentuan umum murabahah dalam bank syariah(Sutan Remy Sjahdeini, 2014) yang meliputi : a) bank dan nasabah harus melakukan akad Murabahah yang bebas riba, b) barang yang diperjualbelikan tidak diharamkan oleh syariah Islam, c) bank membiayai sebagian atau seluruh harga pembelian barang yang telah disepakati kualifikasinya, d) bank membeli barang yang diperlukan nasabah atas nama bank sendiri, dan pembelian ini harus sah dan bebas riba, e) bank harus menyampaikan semua hal yang berkaitan dengan pembelian, f) bank kemudian menjual barang tersebut kepada nasabah dengan harga jual senilai harga beli plus keuntungannya, g) nasabah membayar harga barang yang telah disepakati tersebut pada jangka waktu tertentu yang telah disepakati, h) untuk mencegah terjadinya penyalahgunaan atau kerusakan akad, pihak bank dapat mengadakan perjanjian khusus dengan nasabah, i) jika bank hendak mewakilkan kepada nasabah untuk membeli barang dari pihak ketiga, akad jual-beli Murabahah harus dilakukan setelah barang menjadi milik bank.

Kedua, ketentuan pembiayaan murabahah bagi nasabah yang meliputi : a) nasabah mengajukan permohonan dan perjanjian pembelian suatu barang atau aset kepada bank, b) jika bank menerima permohonan tersebut, ia harus membeli terlebih dahulu aset yang dipesannya secara sah dari pemasok, c) bank kemudian menawarkan aset tersebut kepada nasabah dan nasabah harus menerima sesuai dengan perjanjian yang disepakati, d) dalam jual beli ini bamk boleh meminta nasabah untuk membayar uang muka saat menandatangani kesepakatan awal, e) jika nasabah menolak membeli barang tersebut, biaya riil bank harus dibayar dari uang muka tersebut, f) jika nilai uang muka kurang maka kerugian ditanggung oleh pihak bank, dan bank boleh meminta kembali sisa kerugiannya kepada nasabah.

Ketiga, ketentuan tentang jaminan dalam pembiayaan murabahah yang meliputi : a) jaminan dalam Murabahah dibolehkan agar nasabah serius dangan pesanannya, b) bank dapat meminta nasabah untuk menyediakan jaminanyang dapat dipegang. 
Keempat, ketentuan utang dalam murabahah yang meliputi : a) secara prinsip, penyelesaian utang nasabah dalam transaksi Murabahah tidak ada kaitannya dengan transaksi lain yang dilakukan nasabah dengan pihak ketiga atas barang tersebut. Jika nasabah menjual kembali barang tersebut dengan keuntungan atau kerugian, ia tetap berkewajiban untuk menyelesaikan utangnya kepada bank, b) jika nasabah menjual barang sebelum masa angsuran berakhir, ia tidak wajib segera melunasi seluruh angsuran, c) jika penjualan barang tersebut menyebabkan kerugian, nasabah tetap harus menyelesaikan utangnya sesuai kesepakatan awal.

Kelima, ketentuan tentang penundaan pembayaran dalam murabahah yang meliputi : a) nasabah yang memiliki kemampuan tidak boleh menunda penyelesaian utangnya, b) jika nasabah menunda-nunda pembayaran dengan sengaja, atau jika salah satu pihak tidak menunaikan kewajibannya, maka penyelesaiannya dilakukan melalui Badan Arbitrase Syariah setelah tidak tercapai kesepakatan melalui musyawarah.

\section{a. Mark-up atau Margin dalam pembiayaan murabahah}

Harga jual bank yang disepakati adalah harga beli bank dari pemasok ditambah dengan mark-up/margin dan biaya-biaya yang timbul dari proses pembelian barang tersebut oleh bank. Mark-up atau margin dapat ditentukan baik dalam bentuk suatu lump sum atau menetapkan rasio tertentu terhadap harga beli bank. Mark-up atau margin tersebut hanya boleh ditetapkan satu kali untuk satu kali transaksi pembelian barang oleh nasabah. Bank tidak diperkenankan untuk menetapkan bahwa nasabah tersebut harus membayar margin tersebut dalam jangka waktu tertentu.

Dalam penetapan margin pada murabahah, Otoritas Jasa Keuangan (OJK) mengemukakan ketentuan sebagai berikut (Lukman Haryoso, 2017) : 1) margin jual beli murabahah merupakan tingkat keuntungan yang diharapkan oleh Lembaga Keuangan Syariah (LKS), 2) margin ditentukan berdasarkan kesepakatan antara Lembaga Keuangan Syariah (LKS) dan nasabah, 3) margin dinyatakan dalam bentuk nominal atau persentase tertentu dari Harga Pokok Lembaga Keuangan Syariah, 5) perhitungan margin dapat mengacu pada tingkat imbalan yang berlaku pada pasar keuangan dengan mempertimbangkan ekspektasi biaya dana, risk premium dan tingkat keuntungan, 6) margin tidak boleh bertambah sepanjang masa pembiayaan setelah kontrak disepakati dan ditandatangani kedua belah pihak, 7) Lembaga Keuangan Syariah (LKS) dapat memberikan potongan margin murabahah sepanjang tidak menjadi kewajiban bank yang tertuang dalam perjanjian.

b. Biaya-biaya bank dalam Murabahah

Pengeluaran bank yang dibayarkan untuk memperoleh barang tersebut, seperti pengangkutan/freight, bea masuk dan lain-lain. Biaya ini dapat ditambahkan kedalam cost price dan mark-up/margin tersebut dapat ditambahkan oleh bank ke atas biaya keseluruhan untuk memperoleh barang itu. Biaya-biaya bank lainnya yang tidak terkait langsung langsung untuk memperoleh barang tersebut, seperti sewa gedung, biaya telepon, listri, dan lain-lain tidak dapat dimasukan kedalam harga jualbarang oleh bank kepada nasabah. 


\section{METODE}

Metode penelitian yang digunakan dalam penelitian ini adalah metode deskripstif dengan pendekatan kualitatif. Dalam hal ini berupaya mengumpulkan data, menganalisis secara kritis atas data-data tersebut dan menyimpulkannya berdasarkan fakta-fakta pada masa penelitian atau masa sekarang (A Gima Sugiama, 2008).

\section{Sumber data}

Sumber data dalam penelitian ini adalah sumber data primer, yaitu kepala unit, account officer, dan anggota BMT Daarut Tauhiid sebagai nasabah pembiayaan murabahah di BMT tersebut. Di samping itu juga menggunakan sumber data sekunder yang meliputi modul, dokumen-dokumen di BMT Daarut Tauhiid yang berkaitan dengan topik penelitian.

\section{Teknik Analisis Data}

Teknik analisis data yang dipakai menggunakan model Miles dan Hiberman (Sugiyono, 2017), dengan tahapan sebagai berikut : 1) reduksi data, 2) penyajian data, dan 3). conclution drawing/verification (verifikasi data)

\section{HASIL DAN PEMBAHASAN}

Pengambilan keputusan nasabah BMT Daarut Tauhiid dilatarbelakangi oleh beberapa hal, yaitu :

\section{Citra lingkungan Daarut Tauhiid}

Keputusan nasabah mengambil pembiayaan murabahah di BMT Daarut Tauhiid. adalah karena pengaruh dari citra lingkungan Daarut Tauhid yang religius Islami yang mereka dapat pahami, sehingga nasabah ini percaya dengan kesyariahan BMT tersebut, dimana BMT Daarut Tauhiid ini merupakan salah satu lembaga keuangan mikro yang dibangun dan dikembangkan oleh pesantren Daarut Tauhid. Disamping itu, mereka yang sudah menjadi nasabah sering mengikuti kajian yang diisi oleh Aa Gym. Mereka memiliki asumsi positif terhadap BMT Daarut Tauhiid, bahkan jika BMT bukan bagian dari Daarut Tauhiid maka dia tidak akan melakukan pembiayaan terhadap BMT yang bersangkutan.

Seperti yang diketahui bahwa BMT Daarut Tauhid merupakan salah satu lembaga keuangan mikro yang berada di bawah dan di lingkungan pondok pesantren Daarut Tauhiid. secara tidak langsung, pengaruh lingkungan yang kental dengan nuansa riligiusitas keislaman ini mendorong nasabah untuk melakukan interaksi dengan Daarut Tauhiid yang salah satunya adalah dengan menjadi anggota BMT (Baitul Mal wa Tamwil) Daarut Tauhid.

Akan tetapi tidak semua nasabah BMT mengambil keputusan menjadi nasabahnya berdasarkan citra lingkungan Daarut Tauhiid, hal ini ditunjukkan dengan gambar di bawah ini berdasarkan hasil survey terhadap nasabah BMT Daarut Tahiid : 


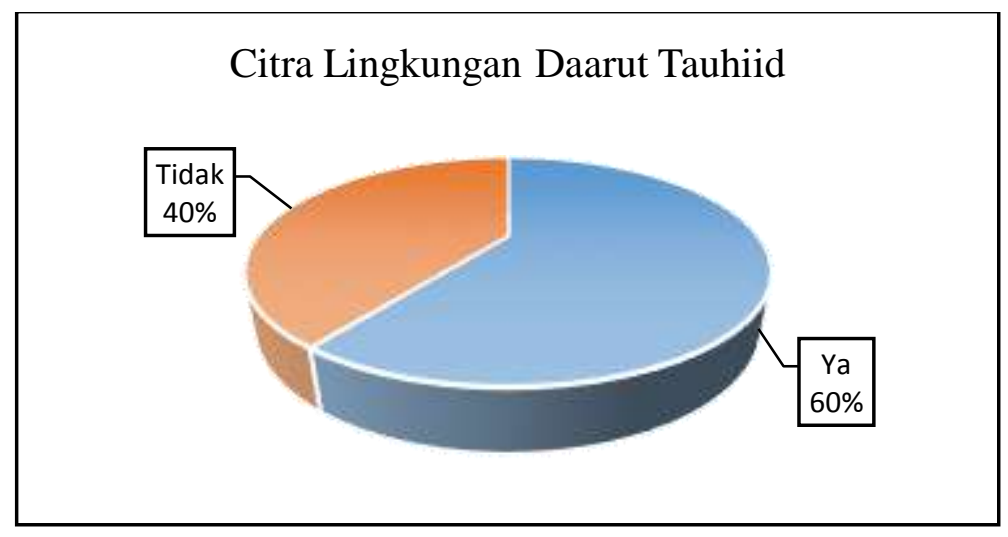

Berdasarkan gambar tersebut, sebanyak 60\% nasabah BMT Daarut Tauhiid memutuskan mengajukan pembiayaan murabahah berdasarkan pertimbangan pada memperhatikan citra lingkungan pondok pesantren Daarut Tauhiid, sedangkan $40 \%$ tidak berdasarkan pada pertimbangan citra lingkungan pondok pesantren Daarut Tauhiid.

\section{Kelompok Referensi}

Kelompok referensi menjadi salah satu faktor pertimbangan nasabah BMT Daarut Tauhiid dalam memutuskan pembiayaan ke BMT yang bersangkutan. Kelompok referensi yang dipertimbangkan oleh nasabah BMT tersebut adalah meliputi pengaruh dari public figure seorang tokoh nasional sekaligus sebagai da'i, yaitu Abdullah Gymnastiar yang lebih dikenal dengan nama Aa Gym, teman sejawat atau teman kerja, keluarga, referensi dari tempat kerja. Hal ini dapat diperlihatkan dalam gambar berikut :

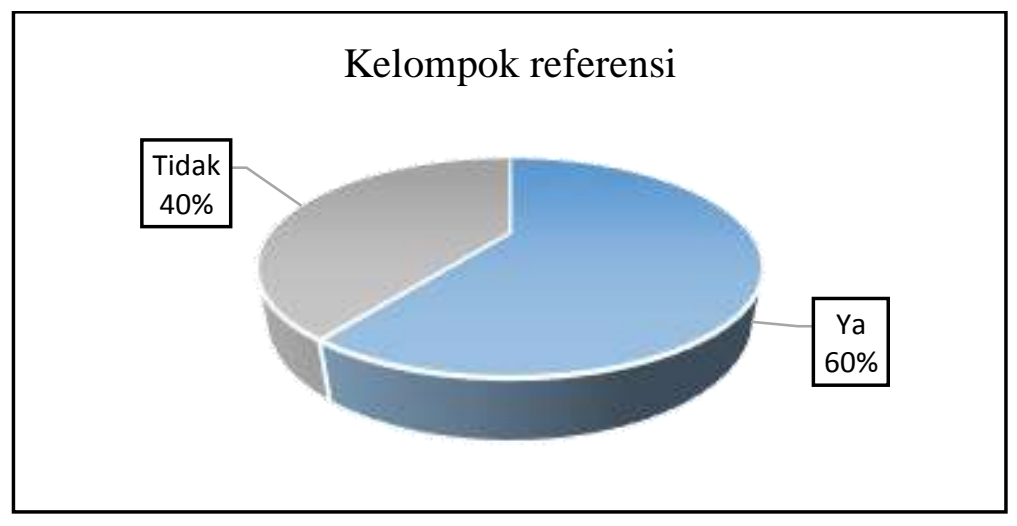

Berdasarkan gambar tersebut, sebanyak 60\% nasabah BMT Daarut Tauhiid memutuskan mengajukan pembiayaan murabahah berdasarkan pertimbangan pada memperhatikan masukan dari kelompok referensi, sedangkan $40 \%$ tidak mendasarkan diri pada masukan dari kelompok referensi.

\section{Kebutuhan nasabah pada situasi tertentu}


Pada saat-saat tertentu yang menjadi sebuah situasi bagi nasabah dapat menjadi latarbelakang neasabah melakukan pembiayaan. Pada satu sisi adanya situasi nasabah yang membutuhkan barang atau jasa pada waktu tertentu sementara pada sisi lain mereka tidak mempunyai dana yang cukup untuk memenuhi kebutuhannya tersebut. Hal ini mendorong nasabah untuk melakukan pembiayaan murabahah ke BMT Daarut Tauhid. Pemenuhan kebutuhan ini dapat terjadi pada saat-saat seperti pemenuhan untuk keperluan sekolah anakanak menjelang tahun ajaran baru, menjelang bulan ramadhan dan hari raya idul fitri dan idul adha, atau situasional lain yang memerlukan pemenuhan kebutuhan dari nasabah. Hal ini dapat dilihat dalam gambar di bawah ini,

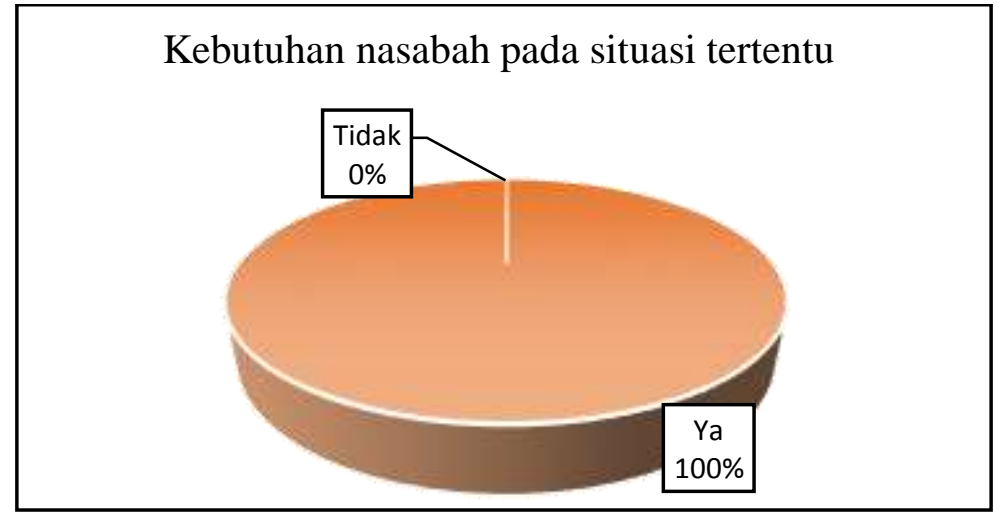

Berdasarkan gambar tersebut, sebanyak 90\% nasabah BMT Daarut Tauhiid memutuskan mengajukan pembiayaan murabahah berdasarkan pertimbangan pada pemenuhan kebutuhan nasabah pada situasi tertentu. Sedangkan $10 \%$ tidak mendasarkan diri pada pemenuhan kebutuhan nasabah pada situasi tertentu.

\section{Penunjang pekerjaan pribadi}

Pengambilan keputusan pembiayaan murabahah yang dilakukan oleh nasabah dilatarbelakangi juga dalam rangka memenuhi kebutuhan untuk penunjang pekerjaan pribadi, baik dalam urusan kewirausahaan maupun dalam urusan pekerjaan kantoran. Sebenarnya pembiayaan penunjang pekerjaan ini lebih bersifat produktif, seperti untuk pembelian kendaraan bermotor karena jarak antara rumah dengan tempat kerjanya cukup jauh, atau juga untuk mempermudah komunikasi berupa handphone ataubahkan alat kerja lain seperti computer, laptop. Faktor penunjang pekerjaan ini menjadi bagian dari hal yang melatarbelakangi nasabah dalam mengajukan opembiayaan murabahah ke BMT Daarut Tauhiid. Hasil survey yang dilakukan ditunjukkan pada gambar berikut, 


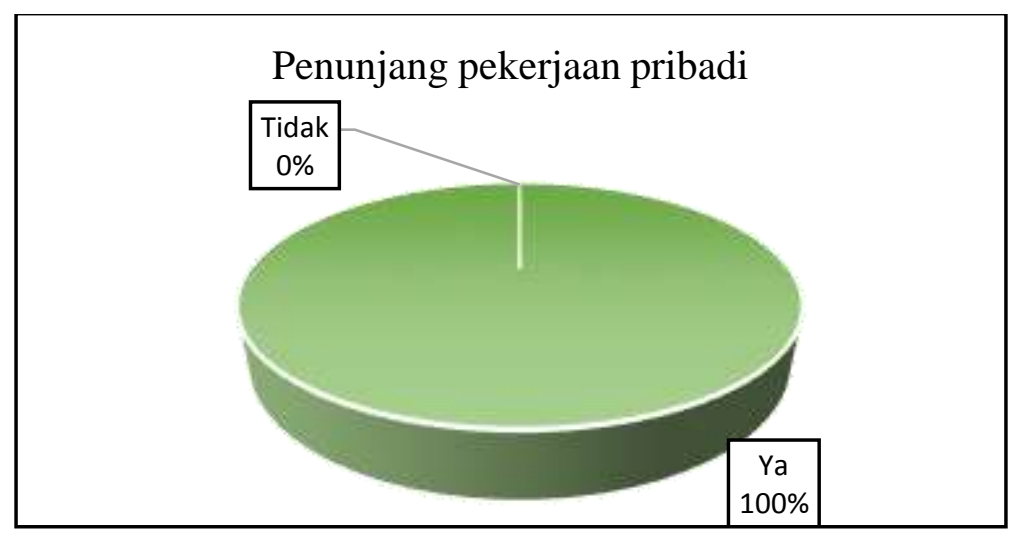

Berdasarkan gambar tersebut, sebanyak $100 \%$ nasabah BMT Daarut Tauhiid memutuskan mengajukan pembiayaan murabahah berdasarkan pertimbangan pada pemenuhan kebutuhan nasabah pada penunjang pekerjaan pribadi.

\section{Persepsi tentang kesyariahan BMT}

Persepsi nasabah terhadap sebuah lembaga keuangan syariah dapat menjadi salah satu hal yang melatarbelakangi mereka dalam memutuskan untuk melakukan pembiayaan ke lembaga keuangan tersebut. Faktor pilihan dari aspek syariah tidaknya menjadi salah satu hal yang dipertimbangkan nasabah terutama oleh nasabah muslim. Kepercayan nasabah berdasarkan persepsinya terhadap BMT Daarut Tauhiid bahwa BMT yang bersangkutan tersebut dalam operasional transaksinya mendasarkan diri pada nilai-nilai syariah menjadi salah satu faktor yang menjadi daya tarik bagi nasabah untuk mengajukan pembiayaan murabahah.

Berdasarkan hasil survey, nasabah menyatakan bahwa mereka meyakini BM Daarut Tauhiid memiliki keamanahan dalam mengelola keuangan sesuai dengan nilai-nilai syariah. Sehingga para nasabah merasa aman dari aspek spiritualitasnya. Hal ini dapat dilihat pada gambar berikut,

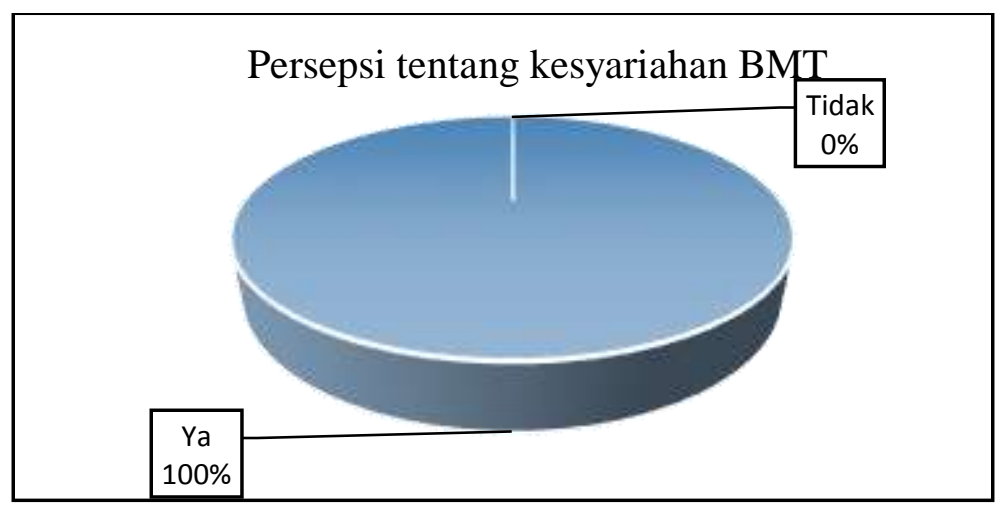

Berdasarkan gambar tersebut, sebanyak 100\% nasabah BMT Daarut Tauhiid memutuskan mengajukan pembiayaan murabahah berdasarkan pertimbangan pada persepsi 
nasabah bahwa BMT Daarut Tauhiid dalam operasional transaksinya mendasarkan diri pada nilai-niali syariah.

\section{KESIMPULAN}

Lembaga keuangan mikro Islam merupakan salah satu solusi dalam pemenuhan kebutuhan pembiayaan bagi masyarakat menengah ke bawah. Keputusan mengajukan pembiayaan yang dilakukan masyarakat sebagai nasabah dalam pengajuan pembiayaan ke lembaga keuangan mikro syariah dapat dilatarbelakangi oleh berbagai hal. Nasabah BMT Daarut Tauhiid dalam memutuskan pengajuan pembiayaan ke BMT yang bersangkutan mempertimbangkan beberapa hal, yaitu citra tentang lingkungan Daarut Tauhiid, kelompok referensi, kebutuhan nasabah pada situasi tertentu, penunjang pekerjaan pribadi, persepsi nasabah tentang kesyariahan BMT Daarut Tauhiid.

\section{REFERENSI}

Abdullah, Thamrin dan Francis Tantri. 2016. Manajemen Pemasaran. Depok : Rajagrapindo Persada.

Abdurrahman, Nana Herdiana. 2015. Manajemen Strategi Pemasaran. Bandung: Pustaka Setia. Assauri, Sofjan. 2015. Manajemen Pemasaran. Depok: PT. Rajagrafindo Persada

Fahmi, Irham. 2016. Teori dan Tekhnik Pengambilan Keputusan Kualitatif dan Kuantitatif. Jakarta: Rajawali Pers

Haryoso, Lukman. 2017. "Penerapan Prinsip Pembiayaan Syariah (Murabahah) Pada BMT BINA USAHA di Kabupaten Semarang”. Jurnal Law and Justice Vol.2 No.1. hlm. 7989

Ikit, 2018. Manajemen Dana Bank Syariah. Yogyakarta : Gava Media.

Kotler, Philip; Kevin Lane Keller, 2008. Manajemen Pemasaran. Jakarta : PT Gelora Aksara Pratama.

Priana, Donni Juni. 2017. Perilaku Konsumen dalam Persaingan Bisnis Kontemporer. Bandung: ALFABETA

Sangadji, Etta mamang dan Sopiah. 2013. Perilaku Konsumen Pendekatan Praktis disertai Himpunan Jurnal Penelitian. Yogyakarta : ANDI.

Setiadi, Nugroho J. 2003. Perilaku Konsumen. Jakarta: Prenada Media

Sugiama, A Gima. 2008. Metode Riset Bisnis dan Manajemen. Bandung : CV Guardaya Intimarta.

Sugiono. 2017. Metode Penelitian Kuantitatif, Kualitatif, dan R\&D. Bandung: Alfabeta. 